\title{
Energy metabolism in pregnant gilts
}

\author{
J. NOBLET (1), W. H. CLOSE $\left(^{2}\right)$ \\ (1) I.N.R.A., Station de Recherches sur l'Élevage des Porcs \\ 78350 Jouy-en-Josas (France) \\ (2) Institute of Animal Physiology, Babraham, CB2 $4 A T$ Cambridge (Great-Britain)
}

An experiment involving I 2 groups of four littermate sisters was carried out in order to study a few aspects of the energy metabolism of the pregnant gilt. In each group, 2 animals were mated and 2 were kept non pregnant, as controls. After mating the animals were fed either I. 8 or $2.5 \mathrm{~kg}$ feed per day. The feed contained I $4.2 \mathrm{p}$. I oo crude protein and II.4 MIJ metabolizable energy $\mathrm{ME} / \mathrm{Kg}$. Each animal was examined at one of the three stages of pregnancy; 50,75 or Ioo days. MEE intake, heat loss, energy, protein and fat retentions were measured by keeping the animal in a calorimeter for a 7 -day period.

The heat production increased and consequently the energy retention decreased with progressing pregnancy. The body weight gain and the total nitrogen retention were higher in the pregnant animals than in their control sister. However, the energy retention, and especially the energy retained as lipids was higher in the latter. The net body weight gain of the pregnant gilts was very similar to the body weight gain of the controls. But the energy and the proteins retained in the maternal tissues of the pregnant animals were lower than the energy and the proteins deposited in the pregnant females. Thus, we did not find any pregnancy anabolism. The maintenance costs $\left(\mathrm{KJ} / \mathrm{Kg}^{075} / \mathrm{day}\right)$ and the efficiency of energy deposition were 420 and 0.80 , respectively, for both pregnant and non pregnant animals. In practice the daily energy requirements of a pregnant gilt are located between 27 and $30 \mathrm{MJ}$.ME.

\section{Contribution to the determination of feed restriction of pregnant sows in an experimental herd subjected to the batch system and to an inten- sive rhythm of reproduction}

\author{
J. CASTAING ('), J. FEKETE (2), M. I,EUILLET (2) \\ (1) Association Générale des Producteurs de Mä̈s \\ $T$, place S.-de-Lestapis, 64000 Pau (France) \\ ${ }^{(2)}$ Institut Technique des Céréales et des Fourrages \\ 8, avenue du Président-Wilson, 75II6 Paris
}

Prior to the application of an experimental programme on the use of the various cereals in sow feeding, we compared two restricted energy levels in pregnant sow ( $R T=5.9$ and $R 2$ $=7 . \mathrm{I} \mathrm{Mcal} \mathrm{D.E.)} \mathrm{i.e.} \mathrm{I.9} \mathrm{and} 2.3 \mathrm{Kg}$ feed, respectively per day and the same daily protein supply during 5 successive cycles. The results concerned a total of 420 litters in the first treatment and $4 \mathrm{I} 2$ in the second one.

The herd was composed of 168 " minimal disease "Large White sows subjected to a batch system including weaning every 3 weeks at a mean age of 26 days. The gilts were mated at puberty and sows which did not exhibit heats two weeks after weaning were culled.

The weight of the sows varied during the cycles according to the level of feed intake. Matingweaning cycle balances became and remained negative at Ist weaning (RI) and at and weaning (R2).

Litter size at birth and at weaning was significantly larger, i.e. on an average 0.5 piglet for the most restricted sows $\left(\mathrm{R}_{\mathrm{I}}\right)$. The mean weight of the piglets at birth was lower in multiparous sows than in young gilts receiving the same diet (a difference of I4.5 p. IOO).

The mortality rate between birth and weaning was little affected by the treatment. The percentage of culling due to reproductive disorders was large $\left(5^{6} \mathrm{p}\right.$. Ioo on an average). The 
number of returns to oestrus was larger with $\mathrm{R}_{2}$, whereas more abortions were observed with RI, especially during the 3 rd and 4 th cycles.

It may be concluded that none of the two restricted energy levels can be considered as satisfactory for pregnant sow feeding.

\title{
VI. - PATHOLOGY
}

\section{Biochemical and haematological profiles in reproductive sows influence of the physiological stage and of the reproductive cycle order}

\author{
E. MEISSONNIER (1), OIga URSACHE (2), L. CHEVRIER ( $\left.{ }^{2}\right)$ \\ (1) I.T.C.F., Station Expérimentale, Boigneville, 9I720 Maisse (France) \\ (2) Laboratoive Central de Recherches Vétérinaives \\ 22, rue Pierve-Curie, 94704 Maisons-Alfort Cedex (France)
}

In an experimental herd of breeding sows subjected to an intensive management system ( 2.5 cycles per sow and per year) and in satisfactory sanitary conditions, blood samplings were made regularly for one year in sows in mid-gestation or in late lactation.

A total of I I biochemical parameters (natrium, potassium, calcium, magnesium, phosphorus, urea, cholesterol, glucose, total protein, albumin, globulin) and haematological parameters (erythrocytes and leukocytes, haemoglobin and haematocrit) were studied in the serum and total blood of 185 sows.

The influence of gestation was characterized by significantly higher calcium, potassium and albumin contents, but lower glucose, magnesium, urea and cholesterol contents as compared with late lactation.

The influence of the reproductive cycle order was marked on several blood criteria: in young sows inorganic phosphorus, erythrocyte, leukocyte and lymphocyte contents were significantly higher than is sows having achieved 5 or more reproductive cycles.

In multiparous sows however, it was noticed that blood variations were accompanied by a progressive weight decrease corresponding to lower gestation net gains, more litters and larger weight losses during lactation.

\section{Pathological consequences of a deficient adjustment of feed supplies to breeding sow requirements}

\author{
F. MADEC \\ Ministère de l'Agriculture, Divection de la Qualité \\ Service Vétérinaive, Station de Pathologie Porcine, B.P. 9, 22440 Ploufragan (France)
}

An ecopathological study was carried out in several sow herds exhibiting non specific pathological manifestations. This study revealed the consequences of feed deficiency on the health and performance of these herds. Although there may be differences between herds the main 